\title{
Sztuczne zapłodnienie z perspektywy bioetyki rodziny
}

\begin{abstract}
Wstęp
W tej publikacji podejmę ważny, moralny problem funkcjonowania współczesnego środowiska rodziny. Uczynię to z perspektywy nowej subdyscypliny bioetycznej - bioetyki rodziny. Ograniczone ramy artykułu, nie pozwalają mi na wyczerpanie tego rozległego tematu, postanowiłem więc skoncentrować się na pojedynczym zagadnieniu, a ściślej na zjawisku sztucznej prokreacji. Obecnie wskutek rozwoju biotechniki, wiele niepłodnych małżeństw czy pozostających w nieformalnych związkach par, może zrealizować pragnienie posiadania własnego dziecka. Sztuczne zapłodnienie stało się więc w pewnym sensie metodą planowania rodziny, naturalnie nastawioną na jej poszerzenie, w przeciwieństwie do farmakologicznych metod regulacji poczęć. Ocena podjętego problemu ukazana zostanie z perspektywy etyki katolickiej (w tym personalizmu) i szeroko pojmowanej etyki świeckiej (głównie utylitaryzmu). Zanim to jednak uczynię chciałbym wpierw scharakteryzować samą ideę bioetyki rodziny.
\end{abstract}

\section{Rodzina w bioetycznym naświetleniu}

Termin „bioetyka” (gr. bios - życie + gr. ethos - obyczaj, zwyczaj) można przetłumaczyć jako etykę życia. Obecnie pojęcia tego używa się również zamiennie z terminami: etyka medyczna, etyka medycyny czy etyka biomedyczna. To nazewnictwo odzwierciedla również definicyjne problemy tej dyscypliny, ze względu na jej rozległy przedmiot badań. Wśród bardzo wielu definicji bioetyki (zarówno tych rozwijanych na gruncie polskim, jak i za granicą) można wyróżnić przynajmniej dwie wersje: węższą i szerszą, rozumienia tej nowej gałęzi nauki. Bioetyka definiowana w wąskim ujęciu to przede wszystkim etyka medyczna ewentualnie etyka medycyny łącznie z jej zawodowym, lekarskim etosem. Natomiast jej szerokie ujęcie poza moralną oceną problemów medycznych

Instytut Nauk Społecznych, Wydział Humanistyczny Akademii Podlaskiej w Siedlcach. 
obejmuje również zagadnienia ochrony środowiska (etyka środowiskowa) jak i zdrowia człowieka.

Osobiście opowiadam się za szerokim rozumieniem bioetyki - etyki życia, które dodatkowo obejmuje nie tylko etykę medycyny i problemy moralne ochrony środowiska społeczno-przyrodniczego ale również i inne rozległe kwestie składające się na wiedzę o życiu (bios) i trosce o jego ochronę, łącznie z promocją odpowiedniego stylu życia (ethos) obejmującego nie tylko aspekt zdrowotny ale również postulat poszanowania wartości życia - zwłaszcza ludzkiego życia.

Bioetyka jest więc dyscypliną otwartą, która cały czas dynamicznie się rozwija i obejmuje swym zasięgiem coraz to nowe obszary ludzkiego poznania. Warto nadmienić, iż Ośrodek Bioetyki Instytutu Etyki Josepha i Rose Kennedych w Waszyngtonie zarejestrował już 22 subdyscypliny wchodzące w skład bioetyki. Ich szczegółowy wykaz został opublikowany w 1994 roku w czasopiśmie „Ethos” wydawanym przez Instytut Jana Pawła II KUL w Lublinie. ${ }^{1}$

Spośród tych subdyscyplin w kontekście bioetycznych aspektów funkcjonowania środowiska rodziny na szczególną uwagę zasługują:

- Etyka początków ludzkiego życia („moment” zaistnienia życia; fazy rozwojowe płodu; moralne problemy poradnictwa genetycznego, diagnostyki i badań prenatalnych itp.).

- Problemy demograficzne współczesnej rodziny (w Polsce i w świecie).

- Zapobieganie ciąży a problem planowania rodziny (etyczne dylematy antyprokreacji: antykoncepcja; sterylizacja etc. oraz naturalne sposoby planowania rodziny).

- Rodzinny kontekst przerywania ciąży (etyczna ocena aborcji; aborcja jako sposób planowania rodziny; ekonomiczne przyczyny usunięcia ciąży itp.).

- Moralne problemy sztucznej prokreacji w kontekście planowania rodziny (technologie rozmnażania $z$ uwzględnieniem klonowania; określanie i wybór płci dziecka; kriobanki nasienia, jaj lub zarodków; macierzyństwo zastępcze itp.).

- Rodzina a problem kształtowania ludzkiej seksualności (etyka seksualna, etyczna ocena zaburzeń w rozwoju seksualnym człowieka).

- Moralne aspekty zmian w modelu współczesnej rodziny (rodziny niepełne; alternatywne modele związków: konkubinaty, związki homoseksualne itp.).

- Rola środowiska rodzinnego w zachowaniu zdrowia fizycznego i psychicznego człowieka (powinność moralna rodziców za prawidłowy rozwój psychofizyczny człowieka).

- Osoba niepełnosprawna w rodzinie (moralne aspekty choroby i cierpienia, status osoby niesprawnej w rodzinie).

- Śmierć i umieranie w rodzinie w etycznym naświetleniu (opieka nad człowiekiem starym i zniedołężniałym, postawy wobec śmierci; problem przedłużania życia i eutanazji).

1 Zob. Bioetyka, „Ethos”, Kwartalnik Instytutu Jana Pawła II, KUL, Lublin 1994, nr 25-26, s. 83-87. 
Należy podkreślić, iż rodziny jako samodzielnej subdyscypliny bioetycznej w wykazie tego amerykańskiego Instytutu Etyki nie ujęto. Właśnie artykuł ten częściowo ma tę lukę wypełnić. Rodzina przecież stanowi podstawową instytucję i strukturę społeczną, w której następuje socjalizacja człowieka, a także zapewnia mu biologiczne i psychiczne warunki prawidłowego rozwoju, nie wspominając już o innych ważnych funkcjach rodziny ze względu na dobre funkcjonowanie społeczeństwa, jak choćby: uregulowanie życia seksualnego, stworzenie mechanizmu wymiany członków społeczeństwa czy zapewnienie jednostce umiejscowienia społecznego ${ }^{2}$. Ze względu na te funkcje rodziny, zwłaszcza prokreacyjne i opiekuńczo-wychowawcze, trzeba przyjąć, iż ma ona wobec zachowania życia i zdrowia jednostki szczególne zadania, dlatego też należy uznać ją za integralny przedmiot badań bioetyki, a nawet proklamować nową dyscyplinę - bioetykę rodziny bądź bioetykę rodzinnąa ${ }^{3}$.

Ponadto w perspektywie etycznej (jak i prawnej) zdrowie i życie stanowią indywidualne dobro każdego człowieka, które posiada również wymiar społeczny, ściśle powiązany z rodziną. Wynika to z prawidłowości, iż wszelkie zaburzenia $w$ środowisku rodzinnym negatywnie wpływają na funkcjonowanie jednostki i jej życie, a to również przyczynia się do regresu potencjału społecznego. Bioetyka rozumiana jako etyka życia musi więc również objąć swymi badaniami sferę środowiska rodzinnego człowieka.

Za powołaniem tej nowej subdyscypliny przemawia także zakres badań bioetyki, zajmujący się różnymi przejawami ludzkiego życia, począwszy od samego początku, poprzez jego osobnicze trwanie, aż po śmierć. Nie sposób więc pominąć wpływu środowiska rodziny na wspomniane etapy w życiu człowieka. W niniejszej publikacji postanowiłem podjąć zagadnienie wspomaganej prokreacji, które stanowi integralną część bioetyki rodziny.

\section{Odmiany prokreacji medycznie wspomaganej}

W literaturze przedmiotu, nie brakuje różnorodnych klasyfikacji metod sztucznej prokreacji, jednak należy zdawać sobie sprawę z faktu, iż dużą ich część należałoby zaliczyć raczej do dziedziny eksperymentów medycznych. Ponieważ w doborze treści kierowałem się zagadnieniami praktycznymi, postanowiłem skoncentrować się na tych odmianach sztucznego zapłodnienia, które stosowane są od dawna w praktyce medycznej, adresowanych do małżeństw, które nie mogą posiadać potomstwa na drodze tradycyjnej.

\footnotetext{
Por. N. Goodman, Wstep do socjologii, przeł. J. Polak, J. Ruszkowski, U. Zielińska, Poznań 1997, s. 189.

3 Por. W. BoŁoz, Zycie wiludzkich rękach. Podstawowe zagadnienia bioetyczne, Warszawa 1997, s. 14.

4 Por. Ibidem.
} 
Postanowiłem więc wydzielić dwie podstawowe odmiany sposobów medycznie wspomaganej prokreacji: inseminacja czyli sztuczne unasiennienie (in vivo) oraz zapłodnienie pozaustrojowe (in vitro). Techniki sztucznego zapłodnienia stosuje się na ogól w sytuacji, gdy narządy rodne kobiety posiadają jakieś wady anatomiczne lub u mężczyzn w przypadku słabej jakości (żywotności) ich plemników bądź anomalii w budowie jego ciała, uniemożliwiających mu odbycie właściwego stosunku seksualnego. Na marginesie chciałbym nadmienić, iż niektórzy autorzy do obszaru wspomaganej prokreacji zaliczają również instytucję tzw. matki zastępczej.

Na samym początku warto zastanowić się czym sztuczne odmiany zapłodnienia różnią się od tego naturalnego ${ }^{5}$. Czy mamy tu do czynienia z różnicą natury fundamentalnej? Jak wiadomo zapłodnienie u osobników odmiennej płci polega na połączeniu męskiej spermy z żeńskim elementem rozrodczym (jajeczkiem). To zespolenie następuje w narządach rodnych kobiety, wskutek kontaktu fizycznego. W przypadku medycznej ingerencji wprowadza się w ten naturalny proces, sztuczny czynnik techniczny, który zastępuje kontakt seksualny ${ }^{6}$. W opinii wielu etyków mamy tutaj do czynienia z sytuacją, która powoduje, iż tego typu zabiegi należy poddać moralnej ocenie. Zacznę od charakterystyki sztucznego unasiennienia (inseminacji).

\subsection{Ogólna charakterystyka inseminacji (sztucznego unasiennienia)}

Zabiegi sztucznego zapłodnienia mają dość długą historię, nie zagłębiając się w szczegóły, można orzec, iż pierwsze tego typu próby sięgają końca XVIII wieku. W 1776 r. Spallanzani przeprowadził udane próby sztucznego unasiennienia u zwierząt, zaś w 1793 r. J. Hunter zastosował sztuczną inseminację homologiczną. Następną ważną datą jest rok 1899, w którym Dickinson zapoczątkował w Stanach Zjednoczonych praktykę sztucznej inseminacji heterologicznej. Od tego czasu właśnie ten kraj należy uznać za współczesną kolebkę tej metody wspomaganego rozrodu. W 1953 r. przeprowadzono zakończony powodzeniem pierwszy zabieg sztucznej inseminacji za pomocą zamrożonej spermy. Także instytucja banków, w których przechowywana jest zamrożone męskie nasienie nie jest nowa, została zainicjowana przez Montegazza już w 1886 roku." ${ }^{7}$ Od okresu

5 Warto nadmienić, iż w literaturze popularnej czy bioetycznej często używa się terminu sztuczne zapłodnienie, który ma wydźwięk pejoratywny. Jednak lekarze czy wielu naukowców polemizują z tym określeniem. Jak wiadomo zapłodnienie jest konsekwencją wniknięcia plemnika do komórki jajowej, a tego procesu nie sposób sztucznie odtworzyć. Postulują więc, aby używać takich nazw, jak np. inseminacja, zapłodnienie pozaustrojowe, zapłodnienie zewnętrzne, zapłodnienie medycznie wspomagane.

6 S. Olejnik, W kregu moralności chrześcijańskiej, Warszawa 1985, s. 264.

7 R. Oтоwicz, Etyczna ocena heterologicznych technik prokreacyjnych, „Przegląd Powszechny” 1991, nr 11, s. 279-280. 
międzywojennego inseminację często stosuje się dla celów hodowlanych u różnych gatunków zwierząt. Efektywne wykorzystanie tego sposobu sztucznego rozmnażania zachęciło do prób przeniesienia ich na ludzi. ${ }^{8}$

Z punktu widzenia technicznego są one proste do wykonania. Zabieg sztucznej inseminacji (ang. artificial insemination) przeprowadza się wewnątrz organizmu kobiety (in vivo - łac. „na żywo"). Polega on na wprowadzeniu spermy dawcy, za pomocą odpowiednich instrumentów w głąb pochwy, do szyjki bądź jamy macicy, albo nawet do jajowodu. Dawca oddaje nasienie dokonując masturbacji. Ze względu na pochodzenie spermy wyróżnia się:

- inseminację homogeniczną (homologiczną) - zapłodnienia dokonuje się przy użyciu spermy własnego męża (partnera);

- inseminację heterogeniczną (heterologiczną) - nasienie użyte w celu zapłodnienia pochodzi od obcego dawcy ${ }^{9}$.

Od strony technicznej te dwie odmiany inseminacji nie różnią się między sobą, lecz biorąc pod uwagę pochodzenie materiału genetycznego mężczyzny, rodzą one dylematy moralne o różnym stopniu nasilenia. Tyczy się to zwłaszcza zabiegów heterogennych, pod adresem których wysuwane są najpoważniejsze zastrzeżenia. Na ogół to rozwiązanie w medycynie stosowane jest wówczas, gdy mężczyzna jest bezpłodny ewentualnie obciążony pewnymi wadami genetycznymi. W takiej sytuacji urodzone dziecko jest więc „w połowie" (bo po matce) genetycznym dzieckiem rodziców.

Nie należy zapominać, iż popularność zabiegów sztucznej inseminacji to efekt dużej liczby niepłodnych małżeństw, które pragną rodziny złożonej z własnego potomstwa. Dane szacunkowe nie są jednoznaczne, mówi się nawet o co dziesiątej, a nawet co szóstej parze, która nie może mieć dzieci z przyczyn medycznych. Duża ich część korzysta wtedy z osiągnięć biotechniki, po to, aby zmienić swoją niekorzystną sytuację. ${ }^{10}$ Szacuje się, iż na calym świecie ponad $1 \mathrm{mln}$ dzieci narodziło się wskutek jednej z metod wspomaganej prokreacji. Nie można więc zbagatelizować wagi tego problemu.

Biorąc pod uwagę charakter artykułu moralną ocenę sztucznego unasiennienia przeprowadzę pod kątem problematyki rodzinnej. Uważam, iż analiza etyczna tych technik powinna brać pod uwagę, przede wszystkim dobro dziecka, które ma zostać poczęte w ten sposób. Powinno więc ono stanowić kryterium moralnej dopuszczalności tego typu ingerencji. Naturalnie ocena ta może być różna w zależności od założeń światopoglądowych autorów. Moje uwagi i refleksje skon-

\footnotetext{
8 S. OlejNiK, W kręgu moralności chrześcijańskiej, op. cit., s. 264.

9 B. PopIElski, Szczególne zagadnienia z pogranicza etyki i prawa, (w:) Etyka i deontologia lekarska, pod red. T. Kielanowskiego, Warszawa 1985, s. 142. Por. W. Guba Ła, Sztuczna prokreacja. Ocena moralna, Warszawa 2000, s. 13-16.

10 T. BRzeziński, Etyka lekarska, Warszawa 2002, s. 167.
} 
frontuję $\mathrm{z}$ argumentacją odwołującą się do szeroko pojmowanej etyki świeckiej (głównie utylitaryzmu) oraz etyki katolickiej (przede wszystkim personalizmu). Moralną wątpliwość praktyk sztucznej prokreacji, niektórzy katolicy zauważyli już na początku XIX wieku. Doprowadziło to do stanowczego potępienia inseminacji w 1897 roku przez kolegium kardynalskie działające w imieniu Leona XIII, które nie podało jednak wyjaśnienia. Problem ten nabrał szczególnej wagi po zakończeniu II wojny światowej, w okresie której miały być stosowane w USA zapłodnienia na odległość $w$ rozdzielonych przez wojnę małżeństwach ${ }^{11}$. Ponieważ problem stosowania technik wspomaganej prokreacji wciąż narastał, teolodzy i etycy postanowili uzasadnić pogląd Kościoła w tej materii. W 1949 roku Pius XII w swym przemówieniu do uczestników IV Międzynarodowego Kongresu Lekarzy Katolickich uzasadnia dezaprobatę Kościoła wobec sztucznych ingerencji w proces zapłodnienia. Papieska krytyka ${ }^{12}$ dotyczyła zwłaszcza trzech przypadków stosowania medycznego unasiennienia. ${ }^{13}$

Za niemoralne należy uznać sztuczne zapłodnienie poza małżeństwem, ponieważ jest ono przede wszystkim niezgodne z prawem naturalnym, które zgodnie z wolą Stwórcy powstanie nowego życia uznaje tylko w sakramentalnym związku, chroniącym godność współmałżonków oraz dziecka. Tylko taki model rodziny jest w stanie zapewnić właściwe środowisko wychowawcze i zagwarantować dobro dziecka. Małżeństwo, które stanowi podstawowy warunek godziwości takich praktyk, nie przesądza jednak o dopuszczalności medycznego zapłodnienia w przypadku, gdy wykorzystuje się nasienie innego mężczyzny (zapłodnienie heterogeniczne). Tego typu praktyki burzą naturalne prawo budzenia życia przez małżonków w ramach fizycznego pożycia oraz naruszają dobro dziecka, gdyż powinno mieć ono zagwarantowane prawdziwe więzy pokrewieństwa. Tylko na prawdziwego (genetycznego) ojca $z$ samej natury nakłada się obowiązek dbania o właściwy rozwój dziecka. Papież również negatywnie ustosunkował się to trzeciego przypadku, w którym dochodzi do sztucznego zapłodnienia nasieniem męża (zapłodnienie homogeniczne), aczkolwiek trzeba przyznać, iż rozstrzygnięcia papieża nie są tu jednoznaczne. Stwierdził, iż cel posiadania potomstwa sam w sobie jest dobry, jednak nie usprawiedliwia stosowania niegodziwych środków, które prowadzą do dehumanizacji procesu przekazywania życia. Dopuścił natomiast stosowanie niektórych ingerencji medycznych o charakterze terapeutycznym, umożliwiających realizację prokreacyjnego aktu małżonków. ${ }^{14}$ Być może

11 Ibidem, s. 166.

12 Tę papieską krytykę można z powodzeniem zastosować do innych form sztucznego zapłodnienia. W dalszych częściach tego paragrafu będę zamiennie stosować terminy: sztuczne unasiennienie (inseminacja) i sztuczne zapłodnienie, aczkolwiek ostateczna etyczna ocena tych zabiegów dotyczyć będzie tylko inseminacji.

13 S. OLEjNIK, W kręgu moralności chrześcijańskiej, s. 264-265.

14 Ibidem, s. 265. 
w przyszłości rozwój tych metod spowoduje, iż dylematy związane ze sztuczną inseminacją przestaną istnieć. ${ }^{15}$

Nie jest moim zamierzeniem szczególowe analizowanie wypowiedzi Piusa XII, chciałbym na razie poprzestać na uwadze, iż krytyczne uwagi zostały podtrzymane i rozwinięte przez następców i wielu etyków i teologów katolickich. Z punktu widzenia szeroko pojmowanej etyki katolickiej ocena medycznych ingerencji w sam proces zapłodnienia jest negatywna. Warto zauważyć, iż Kościół potępia wszystkie odmiany inseminacji, to jednak za szczególnie niemoralne uznaje praktyki sztucznego zapłodnienia poza małzeństwem oraz nasieniem obcego mężczyzny, które rzeczywiście potęgują katalog moralnych zastrzeżeń wobec tych zabiegów ${ }^{16}$. Współcześnie na ogół można się spotkać z trzema rodzajami argumentacji: teologicznej (odwołującej się do prawa naturalnego), etycznej (uwzględniającej dobro dziecka) oraz personalistycznej (mającej na celu ochronę godności współmałżonków oraz poczętego w ten sposób dziecka). Na ogół są one ze sobą ściśle powiązane, co postaram się niżej wykazaćc ${ }^{17}$.

$Z$ punktu widzenia prawa naturalnego wyrażającego wolę Stwórcy, nie godzi się ingerować w naturalny bieg przekazywania życia pomiędzy małżonkami. Niewątpliwie samo pragnienie posiadania własnego potomstwa jest czymś godnym pochwały to jednak nie może się to obyć za pomocą odhumanizowanych metod redukujących człowieka do poziomu zwykłego egzemplarza gatunku. Mamy tu bowiem do czynienia z degradacją osoby ludzkiej (zarówno małżonków, jak i poczętego w ten sposób dziecka). Ten argument natury teologicznej przeradza się więc w uzasadnienie personalistyczne. W opinii etyków katolickich inseminacja stosowana poza małżeństwem oraz w małżeństwie lecz spermą obcego mężczyzny jest czynnikiem dodatkowo pogłębiającym nienaturalność tego

${ }_{15}$ Mam tu na myśli tzw. wspomaganie przy poczęciu. Obecnie najbardziej znaną metodą jest LTOT (Low Tubal Ovum Transfer). Stosuję się nią w sytuacji uszkodzeń lub zrostów jajowodów. Dojrzałą komórkę jajową przenosi się do jajowodu za pomocą laparoskopu omijając w ten sposób przeszkodę zrostową. Następnie małżonkowie doprowadzają do zapłodnienia wskutek aktu seksualnego. Pozostaje to w zgodzie z nauką Kościoła wyrażoną w Instrukcji Kongregacji Nauki Wiary Donum vitae, z 1987 r., według której, „Jeśli środek techniczny ułatwia akt małżeński lub pomaga osiągnąć jego naturalny cel, może być uznany za moralnie godziwy" (DV II B 6) - A. Muszala, Sztuczne zaptodnienie, (w:) Encyklopedia bioetyki. Personalizm chrześcijański. Gtos Kościoła. Pod red. A. Muszala, Radom 2005, s. 434.

16 Krytyka Kościoła wobec sztucznej prokreacji został szczególowo przedstawiona w cytowanym wyżej specjalnym dokumencie poświęconym temu zagadnieniu, opracowanym przez Kongregację Nauki Wiary: Instrukcji Donum vitae. O szacunku dla rodzącego się życia ludzkiego i o godności jego przekazywania (22 II 1987). Ponadto negatywna ocena wyrażona została również w Kodeksie Kościoła Katolickiego (KKK 2374-2379) oraz w Karcie Pracowników Stużby Zdrowia (KPSZ 21-34) opracowanej przez Papieską Radę ds. Służby Zdrowia.

17 Argumentacja odwołująca się przede wszystkim do prawa naturalnego, jak to uczynił wcześniej przytoczony papież Pius XII okazała się obecnie niewystarczająca, należało ją bowiem poprzeć również innymi racjami. 
typu praktyk oraz może przyczynić się do naruszenia dobra dziecka. Dziecko narodzone poza małżeństwem (w konkubinacie, związkach homoseksualnych) może zostać skazane na wychowanie w rodzinie niepełnej, co może źle wpłynąć na jego dalszy rozwój, w przypadku zaś inseminacji heterogenicznej, prowadzić może do wielu komplikacji rodzinnych oraz prawnych. ${ }^{18}$

Reasumując w katolickiej teologii moralnej istnieje nierozerwalna więź między aktem płciowym a poczęciem, wyrażona w osobowej miłości partnerów, której owocem jest dziecko stanowiące również integralną całość tego aktu. Z tego też powodu społeczna nauka Kościoła odrzuca sztuczne sposoby wspomagania prokreacji, ponieważ dziecko, jako dar Boga, zostaje przez instrumentalną ingerencję zredukowane do czegoś w rodzaju obiektu. Sztuczne sposoby rozmnażania przypominają - zdaniem moralistów chrześcijańskich - proces produkcji artykułów przemysłowych, które podważają godność człowieka. ${ }^{19}$

Nie brakuje również moralistów katolickich, którzy potępiają tę formę sztucznego zapłodnienia również za fakt, iż nasienie zostaje pobrane za pomocą masturbacji, co stanowi pogwałcenie moralnego sensu płciowości człowieka, dyskutowano również czy zapłodnienie heterogeniczne należy uznać za formę cudzołóstwa. ${ }^{20}$ Zarzuty te w opinii wielu świeckich etyków należy oddalić, gdyż w tym przypadku intencja towarzysząca tym działaniom nie ma na celu osiągnięcia doraźnej przyjemności czy zdrady lecz chęć poczęcia dziecka.

Etycy o proweniencji chrześcijańskiej uważają, iż najlepszym rozwiązaniem dla niepłodnych par jest adopcja, wtedy bowiem małżonkowie wspólnie uznają cudze dziecko za własne, nie mogąc mieć do siebie żadnych podświadomych pretensji. Dziecko adoptowane również przyczynia się do wzmocnienia więzi małżeńskiej a ponadto nie staje się produktem medycznych ingerencji. ${ }^{21}$ Zgadzam się, iż należy sprzyjać takim decyzjom, gdyż prowadzą one dodatkowo do uszczęśliwienia dzieci porzuconych przez wyrodnych, naturalnych rodziców, aczkolwiek z drugiej strony należy pamiętać, że adopcja cudzego dziecka, które jest czynem chwalebnym, nie może stanowić dla nikogo moralnego obowiązku. Przeciwnicy sztucznego zapłodnienia uważają także, iż tego typu ingerencje nie noszą znamion zabiegu terapeutycznego, gdyż nie przyczyniają się one do wyleczenia, lecz są próbą ominięcia przeszkody. Takie rozumienie sytuacji jest jednak zbyt daleko idącym uproszczeniem. W innych działach medycyny mamy do czynienia z podobnymi wypadkami, np. okulary nie leczą słabego wzroku, ale choremu pozwalają na normalne funkcjonowanie. Niepłodność jest również cho-

18 Por. Z. CZarnik, Techniki sztucznej prokreacji i wladza rodzicielska, „Przegląd Powszechny”, op. cit., s. 292-305.

19 H. DobIosch, Sztuczne zaplodnienie. Ocena moralna wokót powstającego życia, Opole 1991, s. $44-45$

20 T. BRZEZIŃsKI, Etyka lekarska, op. cit., s. 168.

${ }^{21}$ S. OLEjNIK, W kręgu moralności chrześcijańskiej, op. cit., s. 266-267. 
robą, przynajmniej w opinii ludzi nią dotkniętych, zaś niezaspokojenie pragnień rodzicielskich może prowadzić do poważnych zaburzeń psychicznych.

Po ukazaniu krytycznych zastrzeżeń zgłaszanych przez etyków katolickich, chciałbym przedstawić świecki punkt widzenia w tym przedmiocie. Z perspektywy etyki świeckiej moralne uzasadnienie dopuszczalności sztucznej inseminacji opiera się na uznaniu macierzyństwa jako jednego z najpiękniejszych i najszlachetniejszych uczuć. W przypadku, zaś, gdy istnieją ku temu przeszkody, należy je ominąć wykorzystując zdobycze biotechniki. Taka ocena wydaje się wielu ludziom uzasadniona, nic więc dziwnego, iż nie brakuje osób poddających się sztucznemu zapłodnieniu, ich pełnej liczby zresztą nie sposób oszacować.

Najbardziej znany przedstawiciel bioetyki świeckiej, a ściślej odwołującej się do utylitaryzmu P. Singer nie akceptuje krytyki Kościoła wobec wspomaganej prokreacji. Polemizuje m.in. ze stanowiskiem wedle, którego zapłodnienie sztuczne jest „nienaturalne”. Uważa, iż taka obiekcja wypływa z założenia, że naturalny bieg rzeczy jest pomyślny i nie należy go zmieniać. W takim ujęciu również należałoby zakazać ingerencji medycznych w przypadku schorzeń nowotworowych, gdyż "rak” jest przecież naturalnego pochodzenia. ${ }^{22}$ Nie sposób odmówić racji takiemu rozumowaniu, lecz należy mieć na uwadze fakt, iż w tym przykładzie terapeutyczna ingerencja chirurgiczna nie narusza ludzkiej godności, zaś ingerencja w samą istotę procesu inicjowania życia może dla wielu etyków okazać się czymś z natury innym, sprzyjającym depersonalizacji.

Pomijając moją uwagę, należy stwierdzić, iż sposób rozumowania charakterystyczny dla bioetyków świeckich jest bliższy wielu lekarzom i etykom niezależnym, którzy uważają, iż przynajmniej sztuczne unasiennienie w wersji homogenicznej należy zaaprobować. Przytoczony P. Singer i inni utylitaryści uważają, że zabiegi o charakterze heterogenicznym ${ }^{23}$, też są uzasadnione w przypadku, gdy spełni się szereg warunków, takich, jak np. anonimowość (zarówno dawcy jak i biorcy nasienia); pisemna zgoda mężczyzny decydującego się na dobrowolne (bezpłatne) oddanie materiału genetycznego oraz wyrażona na piśmie akceptacja męża (partnera) kobiety poddającej się zabiegowi; dokładne badania lekarskie mężczyzny ofiarowującego nasienie (w celu wykrycia wad genetycznych) itp. Wytyczne te zostały opracowane przez Szwajcarską Akademię Nauk Medycznych w 1981 roku. Tego typu zabezpieczenia miały na celu uchronić przed nieuzasadnionymi roszczeniami o alimenty (zarówno ze strony genetycznego ojca, jak i jego biologicznego dziecka). ${ }^{24}$

22 P. Singer, D. Wells, Dzieci z probówki. Etyka i praktyka sztucznej prokreacji, przeł. Z. Nierada, Warszawa 1988, s. 48.

${ }_{23}$ P. Singer aprobuje wszystkie formy sztucznego zapłodnienia (inseminację i zapłodnienie pozaustrojowe) w wersji homogenicznej, jak i heterogenicznej.

24 T. Brzezı́́ski, Etyka lekarska, op. cit., s. 167-168; 170. 


\subsection{Dobro dziecka i rodziny jako kryterium moralnej oceny technik sztucznego zapłodnienia}

Biorąc pod uwagę charakter tego artykułu moralną ocenę sztucznego unasiennienia przeprowadzę pod kątem problematyki rodzinnej. Niewątpliwie rodzinę należy uznać za dobro, które należy chronić. Wychodzę jednak z założenia, iż rodzina jest instytucją, na pierwszym miejscu realizującą dobro dziecka, które nigdy nie może zostać naruszone, w przeciwnym wypadku podważa swą podstawową funkcję, do której została powołana. $Z$ takim założeniem w zasadzie zgodzą się wszyscy ludzie, bez względu na ich światopogląd. Rodzina jest bowiem miejscem narodzin każdego człowieka, zapewnia mu ona nie tylko materialny byt i biologiczny rozwój ale również odpowiada za jego wychowanie. Należy więc ją uznać za wartość samą w sobie. Ponadto właściwie środowisko wychowawcze sprzyja realizacji wielu innych wartości, które cenimy, jak: równość, sprawiedliwość, solidarność, braterstwo - a więc dotyczących obszaru życia zbiorowego, ale również indywidualnego, np.: godność ludzka, miłość, wolność, odpowiedzialność. ${ }^{25}$

Naturalnie w tej części publikacji interesować mnie będzie szczególnie funkcja prokreacyjna rodziny, której nie można jednak rozdzielać od jej funkcji opiekuńczo-wychowawczej, gdyż tylko wtedy możemy zagwarantować właściwy rozwój narodzonej istoty. Z tego punktu widzenia należy stwierdzić, iż najlepszym modelem środowiska rodzinnego będzie więc para (osób odmiennej płci) złączona węzłem małżeńskim, która w naukach społecznych określana jest mianem rodziny nuklearnej. Nie trzeba nikogo przekonywać, iż w prawidłowym procesie socjalizacji, rozwoju osobowości dziecka, niezbędna jest uzupełniająca się rola rodziców - ojca i matki, wytwarzająca specyficzny rodzaj więzi między nimi. Na ogól stan materialny rodzin pełnych jest również o wiele bardziej korzystny dla dziecka. Małżeństwo w porównaniu do konkubinatu jest również związkiem o wiele bardziej trwałym, a także uregulowanym od strony prawnej co stanowi dodatkowy argument na rzecz upowszechniania właśnie takiego, tradycyjnego modelu rodziny. Jest on znacznie bardziej korzystny dla dziecka, jak i państwa. Znajduje to swoje odzwierciedlenie w przepisach prawnych, które od rodziców wymagają odpowiedzialności za ich dziecko, z drugiej zaś strony zabraniają bez uzasadnionego powodu oddzielać je od obojga rodziców. Dlatego należy przyjąć, iż stosowanie medycznych zabiegów umożliwiających poczęcie dziecka powinno mieć na uwadze rodzinę złożoną z kobiety i mężczyzny. ${ }^{26}$

25 T. SMYczyŃski, Aksjologiczne podstawy dopuszczalności wspomaganej prokreacji ludzkiej, (w:) Wspomagana prokreacja ludzka. Zagadnienia legislacyjne. Pod red. T. Smyczyńskiego, Poznań 1996, s. 162-163.

26 Ibidem, s. 163. 
Należy więc uznać, iż analiza etyczna technik sztucznej prokreacji powinna brać pod uwagę, przede wszystkim dobro dziecka, które ma zostać poczęte w ten sposób. Powinno więc ono stanowić najwyższe kryterium moralnej (jak i prawnej) dopuszczalności tego typu ingerencji ${ }^{27}$.

W mojej opinii, która zresztą nie jest odosobniona, dobro dziecka wymaga, aby odrzucić wszystkie te przypadki inseminacji, które mogłyby doprowadzić w przyszłości do krzywdy mającej narodzić się istoty. Za moralnie niedopuszczalne należy więc uznać inseminację poza małżeństwem, a więc adresowaną do kobiet: samotnych, żyjących w konkubinacie czy w związku homoseksualnym. Za niemoralne należy uznać sztuczne zapłodnienie kobiet w starszym wieku oraz przypadki zapłodnienia post mortem. Postaram się uzasadnić mój pogląd.

Biorąc pod uwagę dobro mającej w przyszłości narodzić się istoty należy potępić praktyki zmierzające do sztucznego zapłodnienia kobiety niezamężnej (panny, wdowy czy rozwódki) ewentualnie żyjącej w konkubinacie, ponieważ najlepsze warunki w jakich powinno wychowywać się dziecko to pełna i trwała rodzina. $Z$ tego tez powodu trzeba potępić przypadki zapłodnienia nasieniem męża lecz po jego śmierci (post mortem), gdyż w ten sposób skazuje się dziecko na rolę sieroty. Nie mamy więc tutaj do czynienia z dyskryminacją praw samotnych kobiet, jak niektórzy argumentują, lecz zakaz ten ma na względzie dobro dziecka. W przypadku osób starszych istnieje również uzasadniona obawa, iż dziecko nie zostanie odpowiednio przygotowane do wejścia w dorosłe życia. $\mathrm{Z}$ analogicznych przyczyn należy negatywnie ocenić sztuczną inseminację lesbijek. Nie znaczy to, że ludzie o skłonnościach homoseksualnych nie mogą dobrze pełnić ról rodzicielskich, lecz różnice w psychice kobiety i mężczyzny powodują, że uzupełniają się oni wzajemnie w procesie wychowania, co ma dobry wpływ na rozwój ich potomstwa. ${ }^{28}$ Dziecko bowiem nie może być traktowane tylko jako środek prowadzący do zaspokojenia indywidualnych pragnień (np. osób samotnych, par homoseksualnych) lecz jako dobro samo w sobie. W sytuacji, gdyby istniała uzasadniona obawa, iż przysługujące nam prawa mogłyby naruszyć dobro dziecka, należy z nich zrezygnować.

Naturalnie w praktyce często się zdarza, iż dzieci poczęte droga naturalną wychowują się w nienajlepszych dla nich środowiskach, to jednak należy odróżnić przypadki prowadzące do sytuacji, na które nie mamy wpływu, od świadomego stworzenia dziecku warunków dla niego niekorzystnych ${ }^{29}$.

$\mathrm{Na}$ osobną uwagę zasługuje problem moralnej dopuszczalności sztucznego zapłodnienia w obrębie małżeństwa, ale w systemie heterogenicznym (spermą obcego mężczyzny). Zabiegi takie mogą bowiem w przyszłości doprowadzić do

\footnotetext{
27 Ibidem.

28 Por. T. BRzeziński, Etyka lekarska, op. cit., s. 169-170.

29 Por. Ibidem, s. 169.
} 
wielu komplikacji rodzinno-prawnych. Aprobata takich praktyk musiałaby być uzależniona od spełnienia wielu szczegółowych warunków, na gruncie prawa, które być może mogłyby uchronić przed tymi komplikacjami (zob. wytyczne Szwajcarskiej Akademii Nauk Medycznych). Pomimo tych prawnych obwarowań, nie ulega wątpliwości, iż dobru dziecka sprzyja stabilna sytuacja rodzinna, którą może zapewnić tylko genetyczne pochodzenie od obojga rodziców. ${ }^{30}$ Dziecko zresztą powinno mieć prawo do znajomości biologicznego ojca. Dlatego takim parom należy doradzić adopcję, skoro ich dziecko i tak w pełni genetycznie nie będzie pochodzić od nich.

Podsumowując dotychczasowe rozważania chciałbym zauważyć, iż wielu niezależnych etyków uważa, iż oceniając sztuczne sposoby planowania rodziny, należy wznieść się ponad spory światopoglądowe i obiektywnie ocenić ich słuszność. Faktem jest, że nie wszystkie małżeństwa chcą wychowywać zaadoptowane dziecko, zaś chęć posiadania własnego, genetycznego potomstwa przez małżonków, nie jest pragnieniem egoistycznym, lecz wynika ono z naturalnych ludzkich potrzeb i skłonności. Ponadto często mamy do czynienia $\mathrm{z}$ faktem, iż adopcja nie może stać się udziałem wszystkich par, ponieważ proces adopcyjny jest bardzo długi i nie wszystkie starające się małżeństwa przechodzą pomyślnie weryfikację.

Dlatego wielu etyków świeckich, jak i lekarzy uważa ${ }^{31}$, że w takich uzasadnionych przypadkach dotyczących małżeństw niepłodnych, nie mających szans na adopcję, inseminacja (unasiennienie) w wersji homogenicznej wydaje się być dostatecznie uzasadniona i moralnie słuszna. Nie zachodzi bowiem obawa, iż dobro dziecka może na tym ucierpieć, a zyska również na tym sama rodzina. W takim przypadku intencję i cel (podobnie jak i przewidywany skutek) trzeba uznać za godny pochwały, a jest nią wzajemna miłość prowadząca do zrodzenia dziecka, jednak z przyczyn od nich niezależnych, podyktowanych schorzeniem, poczęcie musi odbyć się przy współudziale medycyny (działania te stanowią efekt uboczny). Nie mamy więc tu do czynienia $z$ odhumanizowaniem ludzkiego życia lecz z jego afirmacją. Czynnik techniczny, który pozwala zrealizować te pragnienia sam w sobie jest moralnie neutralny, zaś jego kwalifikacja powinna być uzależniona od celu do którego wiedzie. Jeśli technika służy jako narzędzie pozwalające niepłodnym małżonkom zrealizować naturalne pragnienie posiadania swojego dziecka - traktowanego jako dobro wsobne, wspomagana inseminacja w takim wypadku wydaje się być uzasadniona ${ }^{32}$.

30 T. SMYCZYŃsKi, Aksjologiczne podstawy dopuszczalności wspomaganej prokreacji ludzkiej, op. cit., s. 167-168.

31 Por. T. BRzeziński, Etyka lekarska, op. cit., s. 168.

32 Stanowisko takie, które uznaje technikę za czyn moralnie neutralny, jest charakterystyczne również dla niektórych etyków katolickich - np. dla cytowanego już T. Ślipki, aczkolwiek stanowią oni zdecydowaną mniejszość. (Zob. T. Ślipko, Granice życia. Dylematy współczesnej bioetyki, Kraków 1994, s. 145-146.). 
Bioetycy o świeckiej proweniencji, argumentują ponadto, iż lekarzom i psychologom znane są tragiczne przypadki kobiet, których nie zaspokojony instynkt macierzyński przekładał się na różnego rodzaju choroby psychosomatyczne. Dla małżeństw nie zdolnych do poczęcia dziecka w tradycyjny sposób, możliwość spełnienia pragnienia posiadania potomstwa, nawet ze wszelkimi niedogodnościami związanymi z medycznie wspomaganym rozrodem - jawią im się jako wielkie dobrodziejstwo. Decyzja taka opiera się niewątpliwie na subiektywnych i emocjonalnych postawach, lecz z drugiej strony dla dotkniętych niepłodnością małżonków fakt posiadania własnego, naturalnego potomstwa jest niejednokrotnie ich sensem życia, dla realizacji którego właśnie planują założenie rodziny. Znane są przecież tragiczne losy małżeństw bezdzietnych, gdzie brak potomstwa doprowadził do rozpadu związku.

Naturalnie taka świecka interpretacja, nie spotyka się z aprobatą etyki katolickiej, z powodów, które już wyżej w artykule przedstawiłem i uzasadniłem.

Sztuczna inseminacja nie jest jedyną formą wspomaganego zapłodnienia, publikacja ta byłaby znacznie uboższa, gdybym pominął moralne problemy związane $z$ odmianą pozaustrojową.

\subsection{Moralna specyfika zapłodnienia pozaustrojowego}

Zapłodnienie pozaustrojowe (in vitro) ma niezbyt odległą historię. Pierwsze doświadczenia nad tą formą sztucznej prokreacji rozpoczęto w $1950 \mathrm{roku}$, po to, aby dziewiętnaście lat później zastosować je w praktyce. Te eksperymentalne próby ostatecznie doprowadziły do jej zastosowania na człowieku. Po raz pierwszy zwieńczone powodzeniem zapłodnienie poza ustrojem kobiety stało się udziałem J. Rocka i F. Menkina. Jednak za datę symboliczną należy uznać: 25.07.1978 rok, w którym na świat przyszło pierwsze „dziecko z probówki” - Louise J. Brown. Narodziło się ono w Anglii, zaś autorami tego przedsięwzięcia medycznego byli lekarz P. Steptoe i biolog R. Edwards. Próby naturalnie podejmowano dalej, w 1983 roku narodziło się dziecko - rozwinęło się ono z embrionu wcześniej zamrożonego. ${ }^{33}$ Twórcą tej metody był C. Wood. W naszym kraju pierwsze dziecko zapłodnione metodą in vitro (łac. w szkle) urodziło się w 1987 roku w Instytucie Ginekologii i Położnictwa w Białymstoku. Obecnie w Polsce istnieje ok. 30 placówek, które przeprowadzają takie zabiegi. ${ }^{34}$ Ich liczba w skali roku dochodziła nawet do $2500 . .^{35}$

33 R. OTOWICz, Etyczna ocena heterologicznych technik prokreacyjnych, op. cit., s. 280.

34 A. Muszala, Sztuczne zapłodnienie, op. cit., s. 428-429.

35 Por. T. BRzeziński, Etyka lekarska, op. cit., s. 170-171. 
Od strony technicznej zapłodnienie pozaustrojowe (in vitro) różni się zdecydowanie od sztucznej inseminacji, ponieważ przeprowadza się je w retorcie czyli w odpowiednim laboratoryjnym naczyniu („szkle”). Sam proces zapłodnienia nie zachodzi więc w organizmie kobiety (jak w przypadku unasiennienia) lecz poza ludzkim ustrojem w szpitalnym laboratorium.

Zapłodnienie pozaustrojowe (często określane jako FIVET - ang. fertilizatio in vitro and embryo transfer) naturalnie posiada kilka odmian, szczegółów technicznych nie będę jednak przytaczać. Wystarczy nadmienić, iż od strony technicznej tego typu zabiegi polegają na uprzedniej stymulacji hormonalnej organizmu kobiety, w celu uzyskania duzej ilości dojrzałych komórek rozrodczych (na ogół ich liczba wynosi 6-8, dochodzi czasami nawet do 10). Przy pomocy interwencji operacyjnej (punkcji jajnikowej) pozyskane w tej sposób z organizmu kobiety komórki jajowe są następnie przenoszone do probówki z roztworem (zbliżonym do naturalnego) i zapładniane uprzednio przygotowanym nasieniem (przepłukanym i rozcieńczonym w roztworze soli). Sperma męska jest wcześniej przebadana pod względem jakości plemników i w przypadku jej słabej żywotności może być wzmocniona odpowiednimi enzymami. Zygoty ${ }^{36}$ powstałe wskutek zapłodnienia są następnie przechowywane przez około 48 godzin. Dla większej pewności zaistnienia ciąży do jamy macicy operacyjnie implantuje się 2-3 a nawet 4 zarodki (w stadium 2-4 blastomerów). Pozostałe po operacji zygoty w większości przypadków przeznacza się do zniszczenia albo zamraża się w celu powtórnego ich wykorzystania (np. w przypadku niepowodzenia zabiegu) ewentualnie służą do eksperymentów medycznych. ${ }^{37}$

Zapłodnienie zewnętrzne (pozaustrojowe) ze względu na pochodzenie męskiego materiału genetycznego (plemników) dzielimy na:

- zapłodnienie pozaustrojowe homogeniczne (homologiczne) - polega na wykorzystaniu nasienia własnego męża (partnera);

- zapłodnienie pozaustrojowe heterogeniczne (heterologiczne) - sperma pochodzi od obcego dawcy ewentualnie istnieje możliwość zmieszania własnej spermy z nasieniem innego mężczyzny (tzw. spermococtail). Istnieje jeszcze jedno rozwiązanie polegające na pobraniu komórki jajowej od obcej kobiety, która zostanie zapłodniona nasieniem męża (partnera), zaś powstały w ten sposób ludzki zarodek implantuje się następnie do organizmu niepłodnej kobiety. W tego typu wypadkach poczęte dziecko będzie więc „W połowie" (po matce lub po ojcu) genetycznym dzieckiem rodziców. Możliwa jest

${ }^{36} \mathrm{~W}$ mojej pracy często zamiennie będę stosować terminy: zygota - zarodek - embrion. Zdaję sobie sprawę, iz jest to duże uproszczenie, lecz podyktowane zostało ono względami praktycznymi dla potrzeb niniejszego artykułu, która ma charakter przede wszystkim humanistyczny, a nie stricte biologiczny.

37 A. Muszala, Sztuczne zaplodnienie, op. cit., s. 429; H. Dobiosch, Sztuczne zaplodnienie. Ocena moralna, op. cit., s. 26-27. 
również odmiana zapłodnienia w retorcie polegająca na wszczepieniu zygoty, która w całości pochodzi od obcej kobiety i mężczyzny. Mamy tu do czynienia $\mathrm{z}$ najbardziej instrumentalną odmianą technicznej ingerencji w sferę ludzkiej prokreacji. ${ }^{38}$

Po krótkiej charakterystyce technicznej strony zapłodnienia pozaustrojowego należy przedstawić cele, jakim zabiegi te służą, bez tego nie będzie można w pełni dokonać moralnej oceny badanego zjawiska.

W zasadzie jedyny cel powyżej opisanych ingerencji jaki można próbować uzasadnić na gruncie bioetyki - to chęć pomagania niepłodnym małżonkom w narodzeniu ich dziecka. Zresztą z punktu widzenia bioetyki rodzinnej głównie ten aspekt dla moich rozważań będzie istotny.

Niestety techniki in vitro wykraczają poza ten czysto prokreacyjny cel. ${ }^{39} \mathrm{Na}$ etapie dzisiejszego rozwoju medycyny tę odmianę sztucznego zapłodnienia często trudno oddzielić od zabiegów eugenicznych, ponieważ wskutek obserwacji rozwijających się w probówce zarodków, można dokonywać ich selekcji. Warto nadmienić, iż istnieją przedsiębiorstwa, które przechowują także odpowiednio wyselekcjonowane plemniki, po to aby zapewnić przyszłym matkom potomstwo o jak najlepszych cechach genetycznych. ${ }^{40}$ Ponadto w okresie początkowego rozwoju płodu można operacyjnie przeprowadzać odpowiednie korekty na embrionie. Wielu lekarzy uznaje to za dodatkowy pozytywny aspekt tej techniki. Jednak tego typu ingerencje mogą doprowadzić w przyszłości do zbyt daleko idących ingerencji w organizm człowieka, poczynając od zabiegów na komórkach somatycznych kończąc na bezpośrednich ingerencjach na komórkach linii płciowej. Wyżej zasygnalizowane okoliczności towarzyszące zapłodnieniu w retorcie spowodowały, iż wielu etyków przywołuje argument równi pochyłej uważając, iż techniki in vitro doprowadzą w przyszłości do wielu niebezpiecznych dla ludzkości następstw.

Nie mamy tu czynienia z naukową fantastyką. Wszystko wskazuje, iż w przyszłości bioetycy będą się musieli zmierzyć z trudnymi do przewidzenia konse-

38 Ibidem, s. 26.

39 Warto nadmienić, iż naukowcy zgłaszają chęć do przeprowadzania eksperymentów medycznych na "nadliczbowych" embrionach jakie pozostały po zabiegach. Zygoty powstałe wskutek zapłodnienie in vitro można również wykorzystać w przyszłości jako rezerwuar organów do przeszczepów dla chorych pacjentów. Następny cel, to inżynieria genetyczna człowieka, która poprzez odpowiednie manipulacje w początkowym stadium plodu pozwala uodpornić go na różne szko dliwe wpływy środowiska, ewentualnie doprowadzić do innych „pożądanych” zmian w strukturze genetycznej człowieka. Wielu autorów zwraca również uwagę, iż manipulacje na ludzkich genach otwierają drogę do klonowania. Biorąc pod uwagę temat mojego referatu, zawężony do „rodzinnych” aspektów bioetyki muszę te kwestie jedynie wspomnieć, aczkolwiek ich etyczna ocena nie powinna inteligentnym czytelnikom sprawić wiele problemów, trudno bowiem pozytywnie odnieść się do tych ingerencji.

40 H. Dobiosch, Sztuczne zaplodnienie. Ocena moralna, op. cit., s. 27-29. 
kwencjami zapłodnienia pozaustrojowego, które w fuzji z biotechnologią mogą otworzyć drogę np. do świadomego "projektowania” przez rodziców własnego dziecka, i to nie tylko jego płci $^{41}$ (co już jest realne), ale także, koloru włosów, oczu czy innych pożądanych cech fizycznych, a także psychicznych poprzez manipulacje genetyczne na komórkach rozrodczych. ${ }^{42}$

W tym miejscu warto przypomnieć celne, krytyczne uwagi niemieckiego myśliciela J. Habermasa, który uważa, iż stosowanie technik preimplantacyjnych prowadzi do naruszenia tożsamości gatunkowej, dlatego należy je zdecydowanie potępić. Nie można bowiem pozwolić, aby rodzice według mody czy własnej subiektywnej decyzji projektowali odpowiedni model dziecka. Mamy tu do czynienia z daleko idącym urzeczowieniem człowieka i ograniczeniem przysługującej mu wolności. Egzystencja dziecka byłaby więc zdeterminowana genetyczną manipulacją rodziców poważnie ograniczającą odpowiedzialność za jego przyszły los i dokonane życiowe wybory. ${ }^{43}$

W podjętym kontekście powraca również obawa przed klonowaniem człowieka. Zwrócił na to uwagę znany lekarz i bioetyk T. Brzeziński zadając pytanie: „Czy w świetle możliwości wykorzystania jądra komórki somatycznej współmałżonka w celu powstania zygoty da się utrzymać zakaz klonowania istoty ludzkiej?”" ${ }^{44}$ Tego rodzaju zarzuty w negatywnym świetle stawiają praktyki sztucznego zapłodnienia pozaustrojowego.

Obawy o podobnym ciężarze gatunkowym związane są ze spodziewanymi, negatywnymi skutkami zapłodnienia laboratoryjnego, jakie mogą w przyszłości wystąpić. Tych przewidywanych nieszczęśliwych następstw nie wolno bagatelizować, aczkolwiek trzeba skoncentrować się przede wszystkim na realnych zagrożeniach jakie rodzą tego typu praktyki. Należy się zwłaszcza zastanowić, czy mogą się one przyczynić do naruszenia dobra dziecka.

W poprzednim paragrafie ukazałem moralne zastrzeżenia etyków i teologów katolickich pod adresem sztucznej inseminacji. Naturalnie te podstawowe zastrzeżenia moralne obowiązują również w przypadku zapłodnienia poza organizmem kobiety.

Błędem byłoby jednak założenie, iż mamy tu do czynienia z dylematami etycznymi, których ciężar gatunkowy jest zbliżony. Nie chodzi tu bowiem o różnicę natury ilościowej polegającej na tym, iż ta forma zapłodnienia jest o wiele

41 Naturalnie wykorzystanie inżynierii genetycznej do zmiany płci czy innych ważnych cech fizycznych dziecka, należy uznać za niemoralne, ponieważ nie mają one na celu terapii lecz subiektywne upodobania rodziców.

42 Por. F. Fukuyama, Koniec czlowieka. Konsekwencje rewolucji biotechnologicznej, przeł. B. Pietrzyk, Kraków 2004, s. 109-117.

43 J. Habermas, Przyszłość natury ludzkiej. Czy zmierzamy do eugeniki liberalnej?, przeł. M. Łukasiewicz, Warszawa 2003, s. 20-21;27;29.

44 T. BRzezińsKi, Etyka lekarska, op. cit., s. 173. 
bardziej stechnicyzowana od wcześniej opisywanej. Zapłodnienie pozaustrojowe rodzi przede wszystkim nowy problem natury moralnej, który zdecydowanie odróżnia na gruncie etycznym te dwie odmiany sztucznej prokreacji. Zabieg ten prowadzi bowiem do zniszczenia w przyszłości zbędnych, "nadliczbowych” zygot jakie pozostają po "udanym" zabiegu implantacji zarodka do ustroju kobiety. Niektórzy etycy kwalifikację moralną tego typu działań uznają za analogiczną jak w przypadku aborcji (tzw. aborcja selektywna), która narusza prawo do życia istoty poczętej. Ponadto wymienia się również niebezpieczeństwo związane $\mathrm{z}$ uszkodzeniem zygoty, podczas przenoszenia żeńskiej gamety do retorty lub $\mathrm{w}$ trakcie implantacji zarodka do organizmu biorcy. Spowoduje to duże szkody w trakcie dalszego rozwoju organizmu (dziecka) ${ }^{45}$.

Dotykamy więc tu problemu nie tylko moralnego ale również z zakresu antropologii filozoficznej. Z perspektywy etyki chrześcijańskiej bardzo ważne jest określenie statusu antropologicznego zygoty. Przypomnę tylko, iż istnieją dwa stanowiska odnośnie animacji człowieka, proces ten może przebiegać w sposób bezpośredni, albo jak uważają inni - etapami (sukcesywnie).

Wystarczy nadmienić, iż wśród współczesnych etyków katolickich można się spotkać z rzadkim poglądem o tzw. animacji sukcesywnej, która przyjmuje późniejsze uduchowienie zygoty, mające miejsce w 3-4 dniu od jej uformowania się (zakończenie procesu kariogamii). W przypadku zapłodnienia pozaustrojowego wszczepienie zygoty ma miejsce przed tym okresem, dlatego wydaje się, iż w przypadku jej uszkodzenia lub zniszczenia niepotrzebnych zarodków po zabiegu, nie byłoby zabiciem żywej istoty obdarzonej duszą, czyli osoby. ${ }^{46}$

Należy jednak mieć na uwadze, iż stanowisko takie nawet dla zwolenników animacji sukcesywnej (mam tu na myśli etyków o proweniencji tomistycznej) nie oznacza bynajmniej „rozgrzeszenia” praktyk medycznych przyczyniających się do uszkodzenia czy zniszczenia choć jednej nieanimowanej jeszcze zygoty. Jej unicestwienie nie jest równoznaczne z zabiciem osoby, ale nie przekreśla to faktu, iż posiada ona swoisty status moralny, co prawda mniejszy niż obdarzony duszą embrion, ale większy od innych typowych przyrodniczych bytów. W tym właśnie kontekście T. Ślipko ${ }^{47}$ powołuje się na zasadę partycypacji, z której wynika, iż

45 Naturalnie wymienia się również inne hipotetyczne i rzeczywiste powikłania towarzyszące technikom in vitro, jak zapłodnienie słabej jakości plemnikami ( $w$ procesie naturalnym ulegają one selekcji) czy zaburzenia równowagi hormonalnej organizmu kobiety w okresie ciąży. Zabiegi zapłodnienia pozaustrojowego charakteryzują się także małą skutecznością. Tego typu uwagi stanowią dodatkowe kryteria do moralnej oceny tej formy zapłodnienia. (S. Olejnik, Teologia moralna: dar, wezwanie, odpowiedz, t.6., Życie osobiste i współzycie międzyludzkie, Warszawa 1990, s. 258-260.).

46 T. BRzeziński, Etyka lekarska, op. cit., s. 172; T. Ślipko, Granice życia (wyd.2), op. cit., s. 151.

${ }^{47}$ Autor ten uważa, iż stanowisko animacji sukcesywnej jest znacznie bardziej prawdopodobne niż teoria o bezpośrednim obdarzeniu duszą zygoty. 
w osobowej godności człowieka biorą udział wszystkie jego integralne elementy, nawet te w postaci zalążkowej (jak w przypadku ludzkich zarodków), ponieważ są one obdarzone dynamiką rozwojową, z której powstanie w przyszłości w pełni ukształtowana osoba. Dlatego preanimowanej zygocie należy się moralna ochrona, gdyż jest ona „żywym ludzkim istnieniem, zmierza do bycia osobą ludzką i z tego powodu moralna gwarancja bezpieczeństwa dla jej życia i integralności stanowi w pełni uzasadniony postulat normatywny". ${ }^{88}$ Zresztą idea świętości (wartości) ludzkiego życia wymaga, iż w przypadku najmniejszych wątpliwości odnośnie procesu animacji ludzkiego zarodka należy przyjąć zasadę większego bezpieczeństwa, a więc potępić działania przyczyniające się do unicestwienia czy poważnego naruszenia konstytucji zygoty. ${ }^{49}$

Jednak zdecydowana większość etyków katolickich opowiada się za animacją bezpośrednią, przyjmującą uduchowienie zygoty równocześnie $\mathrm{z}$ „momentem” zapłodnienia. Zresztą z punktu widzenia bioetyki nawiązującej do personalizmu, problem animacji jest nieistotny, ponieważ każdy ludzki zarodek wyposażony jest w potencjał osobowych właściwości, z których w przyszłości rozwinie się w pełni ukształtowany człowiek. Zygocie przynależy więc godność osoby, która nigdy nie może być manipulowana i traktowana jako środek do czyjegoś szczęścia. Takie jest również stanowisko Kościoła, które uznaje zarodek za byt ludzki i osobowy, należy więc mu przyznać wszelkie uprawnienia jakie przysługują każdemu człowiekowi bez względu czy znajduje się w fazie życia prenatalnego czy postnatalnego. Mamy tu bowiem do czynienia $z$ rozwojem w czasie tożsamości biografii jednej i niepowtarzalnej osoby. ${ }^{50}$ Dlatego w opinii teologów i etyków katolickich nie można od strony etycznej uzasadnić wzbudzenia życia, które z góry zakłada zniszczenie innych poczętych istot, gdyż tylko wybrane zarodki przez lekarza zostaną przeznaczone do umieszczenia w organizmie matki. Działania mające na celu hodowanie życia pewnych jednostek kosztem uśmiercenia innych uważają za czyn haniebny i zbrodniczy, gdyż narusza się w ten sposób świętość ludzkiego życia. ${ }^{51}$

Po przedstawieniu krytycznych uwag jakie zgłaszają moraliści chrześcijańscy wobec zapłodnienia in vitro, chciałbym się do nich ustosunkować i ocenić badany problem.

Podobnie jak we wcześniejszym podrozdziale poświęconym medycznie wspomaganej inseminacji moralną ocenę zapłodnienia pozaustrojowego dokonam na podstawie nadrzędnego kryterium jakim jest dobro dziecka, a także rodziny (małżeństwa), które stanowi kryterium dodatkowe, pomocnicze. ${ }^{52} \mathrm{Nie}$

${ }_{48}$ T. ŚLIPKo, Granice życia. Dylematy wspólczesnej bioetyki, op. cit., s. 152.

49 Ibidem, s. 159-160.

50 A. Laun, Wspólczesne zagadnienia teologii moralnej. Teologia moralna. Zagadnienia szczególowe, przeł. W. Szymona, Kraków 2002, s. 118-120.

51 S. OLejNIK, Teologia moralna, op. cit., s. 261.

52 Naturalnie to dodatkowe kryterium jakim jest interes rodziny (małżeństwa) nie może kolidować $\mathrm{z}$ dobrem dziecka, które stanowi nadrzędny punkt odniesienia dla etycznych analiz. 
zamierzam jednak powtarzać wszelkich moralnych zastrzeżeń jakie zostały sformułowane pod adresem praktyk sztucznej inseminacji, ponieważ zachowują one swą aktualność również w przypadku technik in vitro. Z tego też powodu należy negatywnie ustosunkować się do heterogennej odmiany tej formy sztucznego zapłodnienia, zachowując linię argumentacji z wcześniejszego paragrafu. Na wszelki wypadek chciałbym w tym kontekście przywołać krytyczną uwagę T. Ślipki, wskazującą na fakt rozerwania „związku między rodzicielstwem a małzeństwem i pozbawienie wskutek tego dziecka właściwej mu moralno-społecznej oprawy życia rodzinnego". ${ }^{33}$ Deklarowane dobro dziecka w heterogenicznej odmianie zapłodnienia zewnętrznego wydaje się zostać poważnie naruszone.

Czy jednak homogeniczne zapłodnienie w retorcie dokonane $\mathrm{w}$ obrębie związku małżeńskiego może zostać zaaprobowane na gruncie etycznym? Naturalnie również w tym wypadku ocena etyczna uzależniona będzie od przyjętych uprzednio założeń antropologicznych, a także światopoglądowych. Przedstawiciele etyki świeckiej, głównie utylitaryzmu (czy innych kierunków etycznych nawiązujących do sytuacjonizmu) unikają rozstrzygnięć bazujących na jakiejś systematycznej koncepcji człowieka, koncentrując się głównie na zagadnieniach praktycznych. Z tych też względów uważają, iż jeśli zrodzenie dziecka za pomocą jakiejkolwiek z odmian sztucznego zapłodnienia pozwoli zrealizować szczytne pragnienia rodzicielstwa, to nie sposób praktyk takich potępić, wręcz przeciwnie należy je uznać za godne pochwały. Należy także uszanować dodatkową okoliczność wielu trudów i wyrzeczeń jakie małżonkowie są w stanie ponieść dla realizacji tego celu, stanowiącego dla nich wielkie szczęście.

Ten sposób rozumowania wielu osobom wydaje się słuszny, ponieważ małżonkom nie sposób odmówić prawa do zrodzenia dzieci, przecież pragnienie posiadania własnego potomstwa we wszystkich znanych nam kręgach kulturowych uważane jest za właściwe. Uważam jednak, iż musi zostać ono uchylone w przypadku, gdyby mogło ucierpieć na tym samo dziecko, które ma przyjść w przyszłości na świat za pomocą ocenianych technik.

W przypadku zapłodnienia pozaustrojowego mamy do czynienia z inną sytuacją, która nie ma miejsca w przypadku inseminacji. Jestem zdania, że jakikolwiek próby uzasadnienia jej na gruncie etyki świeckiej należy uznać za chybione. W tych okolicznościach decyzja małżonków może w nieco innym, niż w tradycyjnie rozumianym sensie przyczynić się do pogwałcenia dobra dziecka. Mam tu na uwadze naruszenie prawa do życia powołanych wskutek zapłodnienia zewnętrznego „nadliczbowych" zygot. Rodzice muszą bowiem okupić przyszłe życie dziecka, zniszczeniem pozostałych po zabiegu niepotrzebnych zarodków $w^{54}$. Przecież posiadają

53 T. ŚL.PKo, Granice życia. Dylematy wspótczesnej bioetyki, op. cit., s. 143.

${ }^{4}$ Naturalnie mogą być również wykorzystane do następnych zabiegów zapłodnienia ewentualnie zamrożone czy przeznaczone do eksperymentów medycznych. Nie zmienia to faktu, iż 
one podobne możliwości rozwojowe zakodowane w ich genetycznej naturze, jak ten wybrany do implantacji zarodek, z którego w przyszłości rozwinie i narodzi się dziecko. Można więc uznać, iż w ten sposób przeciwdziała się tkwiącej w nich realnej możliwości zaistnienia w świecie jako ludzkiej osoby, a więc narusza się ich dobro i osobową godność. ${ }^{55}$ Moja ocena pokrywa się z poglądami etyków katolickich, zwłaszcza personalistów, ponieważ jestem zdania, że ich poglądy w sferze antropologicznej, są jak najbardziej uzasadnione i przekonujące.

Aby w pełni wyczerpać zagadnienia składające się na rozległy obszar sztucznej prokreacji, chciałbym podjąć istotny, moralny problem instytucji, tzw. matki zastępczej.

\subsection{Instytucja macierzyństwa zastępczego w etycznym naświetleniu}

Kończąc rozważania dotyczące wspomaganej prokreacji na koniec chciałbym zasygnalizować zagadnienie jakim jest instytucja macierzyństwa zastępczego (ang. surrogate motherhood). Jest ona specyficzną odmianą wspomaganej prokreacji, ponieważ wykorzystuje się odpowiednią metodę sztucznego zapłodnienia (inseminację lub odmianę pozaustrojową), w celu wywołania ciąży, którą następnie donosi, obca kobieta. Po porodzie dziecko zostaje oddane genetycznym rodzicom. Matka zastępcza spełnia instrumentalną rolę wynajmując odpłatnie (czasami bezinteresownie z powodów altruistycznych) swe usługi bezpłodnym kobietom nie mogącym mieć dzieci na drodze naturalnej, ewentualnie pragnącym uniknąć trudów ciąży. Ten wyżej przedstawiony schemat najczęściej odbywa się w następujących wersjach ${ }^{56}$ :

- homogenicznej (homologicznej) - funkcjonujące jajniki bezpłodnej kobiety, wytwarzają komórki jajowe, z których jedną zapładnia się techniką in vitro spermą męża (partnera), zaś powstałą w ten sposób zygotę operacyjnie przenosi się do łona matki zastępczej. Dzięki tej metodzie przyszli rodzice mogą mieć potomka w pełni z nimi spokrewnionego.

- heterogenicznej (heterologicznej) - stosuje się w przypadku bezpłodnych kobiet o nie funkcjonujących jajnikach. W takiej sytuacji matka zastępcza zostaje unasienniona plemnikami męża (partnera lub w rzadkich przypadkach - obcego mężczyzny) chorej kobiety. W takim wypadku jest ona w połowie genetyczną matką, aby uniknąć tej sytuacji można wykorzystać obcą komór-

W większości przypadków są one niszczone lub nie mają możliwości zrealizowania znajdującej się w nich dynamiki rozwojowej.

55 Warto nadmienić, iż zdarzają się również przypadki komplikacji po zabiegu zapłodnienia pozaustrojowego, które prowadzą do powstania tzw. mnogiej ciąży. Na ogół w takich przypadkach lekarze dokonują selektywnej aborcji, usuwając „zbyteczne” embriony. Praktyki te należy również uznać za wyjątkowo niegodziwe.

56 P. Morciniec, Macierzyństwo zastępcze, (w:) Encyklopedia bioetyki, op. cit., s. 268. 
ką jajową, którą następnie w retorcie zapładnia się nasieniem męża (lub obcego dawcy) a potem zarodek implantowany jest do „wynajętego" łona matki zastępczej. W ten sposób małżonkowie posiadają dziecko, które, w połowie (po ojcu) jest genetycznie z nimi spokrewnione (w przypadku anonimowego dawcy spermy pokrewieństwo nie występuje w ogóle).

- Istnieje jeszcze trzecia odmiana, którą można przeprowadzić w systemie homogenicznym lub heterogenicznym. Z możliwości tej korzystają kobiety płodne, nie mogące lub nie chcące zajść w ciążę. W tej sytuacji następuje zapłodnienie $\mathrm{w}$ wersji in vitro lub in vivo ( $\mathrm{z}$ wypłukaniem zygoty $\mathrm{z}$ macicy genetycznej matki) spermą męża (partnera) lub obcego mężczyzny, następnie zarodek wszczepiany jest do organizmu nosicielki. Urodzone w ten sposób dziecko jest w pełni spokrewnione genetycznie ze swoimi rodzicami, albo tylko w połowie (jedynie po stronie biologicznej matki).

Problem, z którym mamy do czynienia w przypadku instytucji macierzyństwa zastępczego, w opinii wielu etyków jest czymś sztucznym. W zasadzie większość problemów bioetycznych dotyczy ważnych i dramatycznych dla ludzkości kwestii, które powstały jako wynik postępu w naukach biomedycznych. Istnieją jednak takie, które zostały wywołane nie dla szczytnych celów, lecz w sposób sztuczny, motywowany przede wszystkim chęcią zysku, nie mającą nic wspólnego z deklarowaną pomocą dla potrzebujących jej osób. Do takich problemów należy właśnie zaliczyć instytucję matki zastępczej, powołaną do życia przez cynicznych, chciwych lekarzy i innych osób czy przedsiębiorstw pośredniczących w tym niemoralnym, a także w większości krajów bezprawnym procederze. ${ }^{57}$

Naturalnie istnieją raczej odosobnione głosy niektórych etyków o proweniencji utylitarystycznej (np. P. Singera), którzy uważają, iż tego typu zabiegi mogą przynieść pozytywne skutki i przyczynić się do szczęścia przeżywania macierzyństwa niepłodnym (lub nie chcącym z jakiś powodów zajść w ciążę) kobietom. Tego typu argumentacja wydaje mi się daleka od prawdy, co postaram się poniżej wykazać.

Matka zastępcza nie jest tylko nosicielką, którą wynajęto do urodzenia obcego dziecka, jak uważają niektórzy etycy i prawnicy, lecz jest ona prawdziwą matką dziecka, zaś rozwijający się w jej łonie płód - dzieckiem jej macicy i jajników. Nie powinien więc dziwić fakt, iż czasami zastępcza matka nie chce oddać noworodka „prawdziwym” rodzicom, gdyż narodziła się obopólna więź między nią a noszonym dzieckiem. W większości przypadków „wynajętą" matkę należałoby nazwać sprzedawczyniąa ${ }^{58}$, gdyż za pieniądze porzuca urodzone przez siebie

57 J. Bernard, Od biologii do etyki, przeł. J. A. Żelechowska, Warszawa 1994, s. 64-65.

58 Istnieją również nieliczne wypadki, w których kobiety ze względów altruistycznych (bezplatnie) decydują się na zstępczą pomoc w urodzeniu dziecka bezpłodnym osobom. 
dziecko. Należy jednak pamiętać, iż często bywa ona ofiarą swego beznadziejnie niskiego statusu ekonomicznego, który następnie wykorzystują chciwi, cyniczni pośrednicy, wzbogacający się na ludzkiej krzywdzie ${ }^{59}$. Już z tego powodu, redukującego kobietę - nosicielkę do poziomu zwykłego instrumentu, dziecko zaś do roli zamawianego towaru, można takie typu praktyki uznać za naruszające ludzką wartość i zdecydowanie potępić.

Naturalnie nie są to jedyne zastrzeżenia moralne wobec tego typu praktyk, wcześniej wyrażone zarzuty w stosunku do wspomaganej prokreacji, również w tym wypadku zachowrują swą aktualność. Podobnie, jak w przypadku innych odmian medycznego zapłodnienia heterogeniczną wersję macierzyństwa zastępczego należy ocenić negatywnie, zagraża ona bowiem dobru dziecka. Obecność dodatkowej, trzeciej osoby (matki - nosicielki, która często jest również matką genetyczną) dodatkowo komplikuje od strony rodzinno-prawnej ten i tak wyjątkowo złożony układ, co potwierdza tylko jej jednoznaczną, niepochlebną ocenę.

Ponizej znajdują się wypunktowane podstawowe krytyczne uwagi wobec instytucji matki zastępczej, które mogą prowadzić do naruszenia dobra dziecka, jak i kobiety, która zgodziła się urodzić „cudze” dziecko. Oto katalog najpoważniejszych zastrzeżeń wyrażonych $w$ formie pytań wobec homogenicznej odmiany badanego problemu: ${ }^{60}$

- czy kobiety noszącej w swym łonie genetycznie obcy płód nie należy uznać w pewnym sensie za jego matką biologiczną? jeśli tak to jak wpłynie na tę matkę i dziecko późniejsza ich separacja?

- czy chłodny emocjonalnie stosunek matki zastępczej do płodu, wynikający ze świadomości, że dziecko będzie należeć do kogoś innego, nie wpłynie negatywnie na rozwój psychiki dziecka?

- jak należy postąpić w sytuacji, gdy matka - nosicielka pokocha noszone przez siebie dziecko i nie zechce go oddać? do kogo ono należy?

- czy „naturalna” matka która jest dawczynią komórki jajowej, będzie traktować urodzone przez kogoś innego dziecko jak własne?

- co należy zrobić w okoliczności, gdyby narodzone przez wynajętą osobę dziecko okazało się obciążone wadami? czy nie zostanie ten fakt potraktowany jako naruszenie umowy przez matkę najemną? co zrobić z niechcianym i skrzywdzonym w takiej sytuacji dzieckiem?

Naturalnie takich pytań bez zadowalających odpowiedzi jest znacznie więcej i trudno je w pełni rozwiązać na gruncie prawnym, nic więc dziwnego, iż ustawodawstwa krajów Zachodnich praktyki takie zdecydowanie potępiają. Wydaje się więc, iż nawet z pozycji utylitarystycznych odwołujących się do ewentualnych

\footnotetext{
59 J. Bernard, Od biologii do etyki, op. cit., s. 65.

${ }_{60}$ T. BRzEZIŃski, Etyka lekarska, op. cit., s. 173-174.
} 
skutków należałoby wydać negatywną etyczną opinię. Instytucja macierzyństwa zastępczego w ujęciu personalistycznym jawi się jako praktyka wyjątkowo niegodziwa, naruszająca osobową godność dziecka i matki, jak również z powodu nadwerężenia u samych fundamentów moralnej konstytucji małżeństwa i rodziny ${ }^{61}$. T. Ślipko, uważa, iż być może tę etyczną dezaprobatę można byłoby w pewnych skrajnych sytuacjach uchylić, w przypadku, gdyby małżonka nie mogła z powodu choroby zajść w ciążę oraz wykluczono by możliwość odpłatności za wykonaną usługe $e^{62}$.

\title{
Zakończenie
}

Kończąc rozważania podjęte w tym artykule chciałbym zwrócić uwagę, iż problem sztucznej prokreacji wciąż wywołuje emocje. Nie należy się temu dziwić, ponieważ w tym obszarze bioetyki dochodzi do konfrontacji dwóch rodzajów racji: niepłodnych małżeństw pragnących mieć własne dzieci oraz przeciwników ingerencji medycznych $w$ delikatne $\mathrm{i}$ subtelne środowisko przekazywania życia. Należy jednak pamiętać, iż nawet tak szczytne cele, jak posiadanie własnego potomstwa nie mogą być moralnie aprobowane jeśli istnieje, choć najmniejsza, ale uzasadniona groźba, że może na tym ucierpieć dobro dziecka.

\section{The artificial insemination from bioethics of a family perspective}

\author{
SUMMARY
}

In this article I am going to present the moral problems of the artificial insemination from the new discipline- bioethics of a family perspective. This branch of bioethics deals with the moral appreciates of contemporary technical civilization influence function of family's environment. The author takes for granted that a health and a life are an individual right of every man, which has the social aspect too, connected with family. It results from a fact that all disturbances in family's environment have a negative influence on a life and function of an individual, which also contribute to regress of social potential. A family is an unconditional right of every man, which should be protected. In this publication I am going to present the problem of the artificial insemination, which constitutes an integral part of bioethics of a family. The main criterion of the moral appreciate is a right of a child.

${ }_{61}$ Por. T. ŚLIPKo, Granice życia. Dylematy wspótczesnej bioetyki, op. cit., s. 154-155.

62 Ibidem, s. 155. 